Regional Governmentality: Neoliberalization and the Caribbean Community Single Market and Economy

Clare Newstead

College of Arts and Humanities

Nottingham Trent University

Clifton Lane, Nottingham, NG11 8AS

Email: clare.newstead@ntu.ac.uk

Fax: 01158486385 


\title{
Regional Governmentality: Neoliberalization and the Caribbean Community Single Market and Economy
}

\begin{abstract}
January $30^{\text {th }} 2006$ saw the formal launch of the Caribbean Community (CARICOM) Single Market and Economy (CSME). Like many other regional economic initiatives, the CSME is designed create an economic space in which the uninhibited flow of goods, capital and skills across the borders of Member States is anticipated to generate competitive business opportunities and external investment. Despite the intensification of regional programmes, promoters and critics alike continue to consider CARICOM as just an intergovernmental organization, dependent on the political will of Member States as they negotiate the pressures of neoliberal globalization. In this paper, I want to argue that such a framing of regional integration in the Caribbean misses some of the tangible ways CARICOM works beyond the sovereign intent of Member States to enable the encroachment of neoliberal-style economic orders across the space of the region. I adopt a Foucauldian inspired 'analytics of governmentality' to unhinge CARICOM from the government of its Member States. Once free from a persistent statism it becomes possible to consider the technical competencies through which CARICOM initiatives increasingly connect and cohere with neoliberal rationalities. My goal in developing such an analytics is not to suggest CARICOM operates as a superstate but rather to broaden the sites considered relevant to understanding the encroachment of neoliberalism in the Caribbean.
\end{abstract}

\section{Keywords}

CARICOM, governmentality, neoliberalism, regionalism 
January $30^{\text {th }} 2006$ saw the formal launch of the Caribbean Community (CARICOM) Single Market and Economy (CSME) ${ }^{\mathrm{i}}$. The CSME marks a continued but reinvigorated commitment to a more than thirty-year project of regional integration among the predominantly English-speaking Member States. The 1973 Treaty of Chaguaramas establishing CARICOM has been substantially revised; what once offered a bold postcolonial promise "to fulfil the hopes and aspirations of [the] peoples for full employment and improved standards of work and living” (CARICOM 1973: preamble), now declares "market-driven industrial development in the production of goods and services is essential for the economic and social development of the peoples of the Community” (CARICOM 2001). The CSME, therefore, marks not just an effort to revitalize regional integration but a distinct move away from earlier developmentalist initiatives, toward a set of programs and policies focused explicitly on the promotion of an efficient and competitive market determined space (Conway 1998, Dietz \& PantojasGarcia 1994). Caribbean economist Clive Thomas puts it another way when he suggests CARICOM has become "a complicit mechanism with which to facilitate the integration of the region into the global economy - not challenge it" (quoted in Hall 2006).

These shifts in the objectives of regionalism are not unique to the Caribbean. The neoliberalization of regional space reflects broad patterns of transformation in longstanding agreements, such as the European Union, ASEAN, and Mercosur, as well as the guiding rationale behind more recent initiatives such as the North American Free Trade Agreement (NAFTA) (Donegan 2006, Hettne 1999, Mittleman 1996, Shadlen 2008, Smith 1995). There is a tendency in some of this literature to view neoliberal regionalism as largely a response by states to the deterritorializing effects of capital's global stretch, whereby regionalism affords member states certain scale advantages and preferential market access. Heads of Government, CARICOM officials, and their critics alike, have all framed the launch of the CSME in just such terms: as an outcome of decisions by small vulnerable states cast away from old trade preferences into increasingly turbulent global waters (see for example CARICOM 1997b, Commonwealth Advisory Group 1997, Hall 2000, Ramsaran 2002, Thomas C 2005). Neoliberal globalization is seen as an 'inescapable reality' against which the CSME emerges as “the region’s globalization fight back” (CARICOM 2006c).

The gravity of the pressures now impinging on states and peoples in the Caribbean is indisputable. Withdrawal of European preferential trading arrangements, new European Partnership Agreements, trade diversion, and competitive undercutting, have generated different local effects but all contributed to deepening anxiety and economic uncertainty (Bryan 1998, CAFRA 1998, Pantojas-Garcia \& Klak 2004). Yet, framing regional integration in these terms, as a national response to urgent external pressures, has the effect of distracting critical attention away from some of the very tangible ways regional arrangements are actually involved in ordering Development and entrenching neoliberalism in the region. This works in at least two ways.

First, approaching transnational regions in terms of the pressure of neoliberal globalization on the territorially defined nation-state, externalizes the source of market rule to 'the competitive global economy' or US hegemony. This neglects the possibility 
that regions have rich and diverse histories and emerge from conditions much more complex than the inevitable onward march of neoliberalism (Larner \& Walters 2002). It also reinforces a view of neoliberalism as homogenous, hegemonic and inevitable. Scholarship within geography and anthropology has begun to counter narratives of the universal sweep of the market with calls to explore particular expressions of neoliberalism as ambivalent and contradictory assemblages (Bergeron 2001, Larner 2003, 2005, Ong \& Collier 2005, Peck \& Tickell 2002). Particularly useful are analyses that approach neoliberalism as a diverse set of techniques and rationalities through which market-order is extended and new neoliberal spaces and subjects brought into being (Ferguson \& Gupta 2002, Larner \& Le Heron 2002, Mitchell K 2006). Larner (2005), for instance, argues that paying attention to particular manifestations of neoliberal ideas, and the mobilities and biographies that underpin new political and economic configurations, is "likely to reveal hybrid multi-vocal configurations rather than unified and coherent political formations” (11). Such work reflects a twin desire to understand, on the one hand, how neoliberalism reterritorializes in disparate locations, and on the other how, despite its apparent ability to take hold anywhere, it remains uncertain, tentative and unstable. Such a dual project might be possible in relation to CARICOM if the institutional arrangements are approached as a site of uncertain but nevertheless effective connection with neoliberal rationalities.

Second, while the narrative of globalization-induced state transformation singularizes and simplifies neoliberalism, it also positions the state as the primary actor determining reactions to economic change. Placing the power to determine regional practice solely in the territorially defined nation-state, such a narrative locates national governments as the legitimate institutional framework through which power is exercised and negotiated in the space of the region. Yet, as work by Staeheli \& Cope (1994), Walters (2004) and Swyngedouw (2005) suggests, there is evidence to indicate that within regions new and potentially ambivalent forms of governance are emerging that exceed the regulatory frame of the nation-state. For this reason, Larner and Walters (2002) suggest that, just as Foucault highlighted the 'governmentalization of the state' through which "the state became connected to a heterogeneous field of governmental technologies", we might now usefully examine the processes through which "the region emerges as a site of competing political strategies and as an instrument of government” (423; see also Rose 1996).

A number of studies of regionalism now question the focus on state reactions to endogenous pressures (Hettne 2005, Jayasuriya 2003, Phillips 2003). Marchand, Bøås and Shaw (1999), for instance, argue that regions emerge from diverse "linkages among a heterogeneous set of actors and realms, including states, economies/companies and societies/civil societies" (897). Moving beyond regions as merely inter-state institutions in the way they suggest makes it possible to include a broader range of actors and issues as active in determining the nature of regional formations (Gamble \& Payne 1996). Moreover, such work has also begun to consider the capacity of regions to shape, rather than just respond to, changes in the world order. Phillips (2003), for example, examines the influence of corporate activities and investment decisions in shaping the South American region mapped by Mercosur. Her work suggests not only that non-state actors produce regionalisms but that such regionalisms can in turn shape state practices. 
Attention to the multiple and varied associations involved in producing regional spaces is important. Feminist activists, indigenous groups, professional organisations, and external institutions, such as the World Bank and European Union, each engage with Caribbean regionalism. Critical scholars have also long claimed regionalism as necessary for small states in an imperial world order (Beckford 1972, James 1981, Nettleford 2003, Thomas CY \& Brewster 1967). Such diverse presences might represent 'sites of translatability' in the extension of power across the region (Rose \& Miller 1992). They equally provide interesting vantage points from which to consider the complexity and ambivalence of regional formations in relation to neoliberal globalization (Newstead 2005). Unpacking some of these diverse formations and their implications for the practice of particular types of social organisation and political subjectivity is important work. However, my goal in this paper is somewhat different. I am concerned with the specific task of highlighting the governmental work performed through CARICOM instruments and arrangements.

CARICOM is popularly viewed as simply a weak and ineffective institution, failing to meet targets and beleaguered by the political insularity of its Member States (Bernal 1994, Pantin 2004, Schiff \& Winters 2003). This understanding, however, leaves unexamined the many routine practices through which CARICOM engages in the neoliberalization of regional space. The consistent externalization of uncertainty in the preambles of CARICOM treaties and programme documents is just one example of how institutional activities work to make self-evident and acceptable conduct in keeping with market-led Development. Officially, CARICOM is an intergovernmental organization. Yet, by unhinging it partially from its state connections, it becomes possible to consider how such an institution works to constitute and order the spaces and subjects of the region in relation to neoliberal economics. This is not to suggest that national governments in the region are now beholden to a supra-national entity. Rather, it is to recognize and interrogate some of the subtle, yet practical processes potentially constituting the neoliberal governmentalization of the region. My goal in advocating such an analysis is to consider how we might better understand expressions of neoliberalism in the Caribbean as fragile projects in motion if we actually include CARICOM as one of a range of active sites through which market order is organised and extended. In the next section, I set out an analytics of governmentality, which I suggest offers useful tools and guides for unpacking some of the work CARICOM performs. In the remainder of the paper, I introduce a range of CARICOM techniques through which the region is increasingly inscribed, ordered and made amenable to interventions in keeping with neoliberalism.

\section{Governmentality beyond state effect}

Foucault's (1991, 2007) work on governmentality has been instrumental in shifting the focus of research on government, rule and order, away from legislative politics and territorial sovereignty toward the manifold points at which power "invests itself in institutions, becomes embodied in techniques, and equips itself with instruments and eventually even violent forms of intervention" (Foucault 1980: 96). This alternative analytics of power moves away from an emphasis on rule through obedience to the law to examine government in terms of the 'conduct of conduct' and the interest of modern states in managing their populations 'at a distance' through "countless, often competing, local tactics of education, persuasion, inducement, management, incitement, motivation 
and encouragement” (Rose \& Miller 1992: 175). Foucault's interest centred on the relationship between states and their subjects but the attention of an analytics of governmentality to the dispersed and often extra-territorial processes through which conduct is ordered highlights the political significance of practices of rule outside the direct authority of the state (Rose \& Miller 1992, Sharma \& Gupta 2006).

Lemke (2001) identifies two key aspects to the 'art of government': first, are fields of representation, through which the concepts, objects, borders and spaces to be governed are delineated and defined; and second, are forms of intervention practiced through techniques, agencies and institutions (191). An analytics of governmentality, therefore, concerns itself with understanding how practices of representation and intervention combine to constitute things - issues, spaces, communities, individuals - as governable objects (Dean 1999). Rather than dismissing regional agreements as simply instruments of national government such a perspective shifts attention to the task of interrogating how such arrangements are implicated in constituting regional space and regional subjects as a governable. Understanding CARICOM this way requires attention to the knowledges, agencies and practices through which it brings together disparate locations in a shared sphere of governance, regulation and management.

Rose and Miller (1992) map a similar two-fold distinction when they divide their analysis of the problematics of government into political rationalities and governmental technologies. Their conceptualization, however, reflects their particular concern with the relationship between rule at a distance and specific forms of economic organization in 'advanced liberal democracies'. Political rationalities are modes of justification, or "the ideals or principles to which government should be directed", as well as practices of representation (179). Rose and Miller (1992) refer to ideals of freedom, equality, efficiency, and wealth, but it is also possible to consider, for example, family, nation or self-determination. Governmental technologies are forms of intervention or the means through which programmes of government "become capable of deployment" and "a multitude of connections are established between the aspirations of authorities and the activities of individuals” (Rose and Miller 1992: 183). In advanced liberal democracies, Rose and Miller (1992) note techniques for the rationalization of market exchange including processes of standardization, calculation, examination and assessment. Such practices are significant for their ability to bring differences into the orbit of norms and relocate problems "from the disputed terrain of politics...onto the tranquil yet seductive territory of truth" (188; see also Barry 2002). It is this sort of transference which makes possible state roll back and deregulation despite an intensified range of technical methods designed to manage and extend "the field within which a certain kind of economic freedom might be practiced in the form of personal autonomy, enterprise and choice” (Barry, et al. 1996: 10).

Recent work by geographers has begun to examine some of the techniques for coordinating neoliberal transformations 'at a distance' (Ward \& England 2007). Katharyne Mitchell's (2006) examination of European Union policy on education and training for immigrants and second-generation minorities, for instance, reveals how an emphasis on standardization and transferable certification contributes to a shift in the purpose of education policy, from promoting democratic citizenship to the production of individually responsible, skilled and mobile labourers; indicative of 'encroaching 
neoliberalism'. Larner and Le Heron (2002), in their analysis of changes in the retail and banking sector in New Zealand, similarly note an intensified individualism consistent with an emphasis on creativity, entrepreneurialism, performance, and consumption. This work illustrates that neoliberal rationality is not some inexorable force or ideology to which all will fall but a particular set of ideas and practices that multiple agents assemble and enact in diverse and complex ways in different locations. A useful way to begin understanding the relationship between regional arrangements and neoliberalism then is with the specific and conjectural task of explaining how particular configurations, such as CARICOM, come to be connected to market rationalities (Dean 1999). How, for instance, do CARICOM practices of inscribing the region through statistics, regional regulations and geographic imaginations, work with varying degrees of effectiveness, to bring disparate entities within the region into intelligibility with the logic of the market?

An analytics of governmentality suggests varied possibilities for understanding current social transformations through a recognition and analysis of new spatialities of government. Yet, despite an emphasis on 'dispersal', there is often a tendency within the literature to trace scattered modes of government back to the territorially defined state (Larner 2003, Rose-Redwood 2006). Timothy Mitchell’s (1999/2006) influential work on Development, for instance, moves away from a view of state power as territorially bound to highlight the 'rule of experts'. Yet it focuses on the apparent conundrum that "despite their localized and polyvalent nature, disciplinary powers are somehow consolidated into the territorially based, institutionally structured order of the modern state" (2006: 178). It is the state that is "the powerful, apparently metaphysical effect" of the varied techniques, organizations and practices it claims to enframe (2006: 180; see also Ferguson \& Gupta 2002, Gupta 1995). Mitchell’s work usefully demonstrates how practices that claim to emanate from a state entity actually work to produce the state as a legitimate site of authority but it does little to develop the invitation of an analytics of governmentality to interrogate how different spatial objects come into being.

Sidaway (2002) develops a similar line of argument to T. Mitchell, in his study of Southern African regionalism. He views regionalism as a dispersed process that works to produce the effect of sovereign statehood in a context where sovereignty is fragile and practically eroded. Like CARICOM, the Southern African Development Community (SADC), which forms the focus of his study, is often interpreted as an ineffective institution. However, contrary to this discourse of failure, Sidaway reveals the productive effects of regional integration in relation to state sovereignty. He argues regional organizations in the Global South are not necessarily designed to be fully operationalized according to their official mandates but are better understood as representative practices through which state sovereignty is acted out (see also Montecinos 1996). The fanfare of annual conferences, international meetings, and the plethora of treaties and agreements to which member states become signatories, are all performances through which the state is 'magicked into existence'. The creation of regions, according to Sidaway, reminds communities "that the states of which it is formed apparently exist as sovereign, tangible, real things (rather than, for example, as contested, simulated and ramshackle sets of social relations masquerading as states)" (38). 
In some respects, the institutional practices performed through CARICOM are similarly productive of state sovereignty. CARICOM was established as a strictly intergovernmental organization and the aim of advancing sovereignty and independence was explicit at its foundation. It was not by any means intended to transgress on the hard won political sovereignty of Member States (Blake \& Hall 1980). The CARICOM institutional arrangement reflects this hierarchical ordering of political space. The official decision making body of the Community is the Conference of the Heads of Government. Each member state has one vote at the Conference, decisions must be unanimous, and any one state can exercise the ultimate authority of veto. All decisions must be passed through national legislative frameworks and enacted into Domestic Law before they become legally binding. Statism is further rationalised through a striking absence in agreements, publications, and communiqués of any reference to the space represented by CARICOM as a territory. Without a territory CARICOM cannot claim legitimacy in the name of the people; it has no right to govern, and can never be anything more than an instrument of national governments. Other mundane practices, such as the national flags that frame both the entrance to the CARICOM Secretariat in Georgetown, Guyana, and its virtual equivalent online, similarly represent state sovereignty.

The analysis offered by Sidaway (2002) is insightful, not least for its attention to the distinct features of post-colonial regionalism. However, it suggests the significance of regional agreements rest largely in their functioning as techniques for reproducing the distinction and exteriority of the state. Yet, as the following sections illustrate, CARICOM practices also function in making 'the region' visible for intervention and coordination. As Walters (2004) suggests, there is much to be learned by considering the "governmentalization of space between, above, or across the system of states" (155; see also Larner \& Le Heron 2004). Approaching the European Union as a mentality of government, he recommends, "interrogating the particular subjects, objects, arts and spaces [regional formations] bring into being” (156). This does not preclude the state but it does encourage an interrogation of other spaces and 'geo-coded' landscapes, including the region itself (Rose-Redwood 2006). Walters (2004) explores how tabulations, cultural programs and signs at airports make the EU visible and calculable; he also stresses the significance of particular sets of knowledges and technologies of intervention, such as planning, through which it becomes possible to "both see and act on 'Europe'” (163). Such modes of practice may reassemble existing knowledges and technologies into new configurations but they may also involve the development of new arts of government including, in the case of the EU, harmonization and denationalized forms of citizenship (Walters 2004). Evidence of such new arts of governemnt leads Donegan (2006) to suggest, in his analysis of NAFTA, APEC and the FTAA, that neoliberal regionalism might better be understood "as a means of governing states" $(25)^{\mathrm{ii}}$.

The three sections that follow examine some of the governmental technologies associated with regional arrangements in the Caribbean: first, practices that make the region intelligible as 'a region'; second, the sorts of subject positions made available by CARICOM; and, lastly, the anti-political effects of CARICOM's role in providing technical support and local expert knowledge. While other rationalities, such as 
developmentalism, are still associated with regionalism in the Caribbean, my focus is on the practices that mesh favourably with a neoliberal rationality and its emphasis on the merits of market rule, individual and corporate freedoms, entrepreneurialism and selfdetermination. My aim is to address how regional agreements in the Caribbean contribute to configuring regional space as a governable object and thereby, demonstrate the importance of engaging regional policies politically.

\section{Smooth regional economic space}

At a recent symposium on the CSME, Enid Bissember (2006), of the CARICOM Secretariat Economic Intelligence and Policy Unit, presented a draft of a CARICOM Financial Services Agreement. The meeting, held in Barbados, was designed to discuss issues such as monetary cooperation, macro-economic policy harmonization, production integration and institutional strengthening; matters considered "critical for economic development and transformation in the context of the evolving CARICOM Single Market and Economy” (CARICOM 2006a). Fiscal harmonization is one of a number of priority areas considered fundamental to the success of the CSME. The objective of the Agreement, according to Bissember (2006), is to create a "seamless financial space" as a base for global competitiveness. Such a space, she suggests, will lower transaction costs, provide consumers with greater choice and ultimately produce economic growth and increased employment. What is significant about Bissember's presentation, and others made at the same meeting, is they offer market freedom as the guiding rationality behind the proposals and link this directly to a set of comprehensive frameworks designed to produce a smooth, seamless regional economic space.

The smoothing out of regional space through the CSME extends across a domain of objects, and engages a range of practices of representation and intervention. It involves the harmonisation of the legal frameworks governing the free movement of capital, goods, services and some persons; rights to establishment throughout the region, national insurance transferability and the standardization of company law, financial services regulation and competition policies. The CSME also requires Member States to establish comparable national competition authorities, standards bodies, and accreditation infrastructures. Operationalizing these changes has involved making national legislation visible and subject to a series of reforms and 'roll backs'. The original Treaty establishing CARICOM was a slim document expressing a broad commitment to cooperation. In contrast, the more substantial Revised Treaty elaborates the obligations of signatory states and outlines in detail national policies subject to removal and those prohibited under the new agreement. In the area of financial regulation, for instance, the Treaty prohibits signatory states from introducing any new measures affecting the movement of capital or the regulation of financial services, and requires them to withdraw existing legislation in both areas. CARICOM publishes detailed schedules and timetables for compliance to these neoliberal-style reforms on its website, along with the status of implementation of agreements and action still required.

Contrary to the narrative of regionalism as a national response to global competition, and despite the fact that Member States were outwardly the architects of the Revised Treaty, measures to advance the CSME increasingly serve as instruments to govern the acceptable limits of national regulation within regional space. Member States must all adopt the new regulations into national law before they become effective but a range of 
techniques now exist to ensure this is conducted in a timely and orderly manner. In 2005, CARICOM launched CARICOMlaw.org, a secure website mandated "to provide support to Member States in the discharge of their Treaty obligations". The site complements the disciplinary effects of the timetables and schedules for compliance by providing details on national legislation, records of accession and implementation by Member States. The Revised Treaty also contains provisions for regional committees, such as the Council for Finance and Planning (COFAP), to "recommend measures to achieve and maintain fiscal discipline by the Governments of the Member States” (CARICOM 2001). National governments must report to COFAP and submit to regular monitoring of applied procedures. The Revised Treaty provides some scope for national economic manipulation, particularly in relation to balance of payments adjustments (Article 43). However, it limits the provisions as short-term (18 months) and provides COFAP with responsibility for imposing a schedule for reversal and for recommending necessary permanent adjustments to avoid future difficulties.

These sorts of visibilities are not coercive - states can and do refuse to oblige; and they withdraw and stall from implementation procedures. The Bahamas has rejected the opportunity to join the CSME based on considerations relating to its relationship with the United States, while the members of the sub-group the Organization of Eastern Caribbean States stalled their ratification of the Revised Treaty until satisfactory provisions were in place to assure special protections for small economies. However, routine monitoring practices do have disciplinary effects (Gupta and Ferguson 2002). In 2005, in his introduction to CARICOMlaw.org, Dr. Winston Anderson, General Counsel for the CARICOM Secretariat, highlighted the potential governmental role of the visibilities produced by monitoring when he suggested "an inventory of draft legislation and regulations will also provide a constant reminder and stimulus for required action for Member States” (CARICOM 2005). Publicity materials, private sector seminars and a touring 'CSME Caravan' communicate a similar message. Moreover, in 2001, CARICOM facilitated the introduction of the Caribbean Court of Justice (CCJ), which, in its original jurisdiction, acts as an international court for the interpretation of the rules of the CSME. Contrary to the rationalities of economic freedom and flexibility, therefore, the CCJ now promises new mechanisms for coercive measures against those signatory states in violation of the new rules.

The sort of 'technologies' currently employed by CARICOM in the name of the CSME work to produce such a thing as a 'regional economic space'. They do not equate to neoliberalization but enhance "the possibility of a liberal governance of greatly extended social and economic spaces” (Walters 2004: 166, emphasis added). This has significance at a number of levels. For instance, CSME initiatives help produce 'the Caribbean economy' as a field of visibility within the global economy. Thus, while the timetables and schedules produce national laws as objects for intervention, they also distinguish the region as a single economic space, polished with legal reforms and absent the frictions unattractive to foreign investment. Equally, the CSME projects 'the region' inwards toward a possible 'region people'. According to CARICOM (2007), the CSME “is intended to benefit the people of the Region by providing more and better opportunities to produce and sell [their] goods and services and to attract investment". Here too, 'the region' is an investment space but one that is entrepreneurial and abundant with the 'freedoms' this affords to exchange and maximize market opportunities. 
Producing this kind of economic smoothness, however, requires the removal of other types of friction. Deviant behaviours such as crime, drug trafficking and money laundering, have all become targets for intensified regional initiatives, which further inscribe the region as a stable and tough juridical space, safe for international investment. Of greater concern, however, is that safety and security for investment has historically required the containment and erasure of other kinds of uncooperative behaviour within the region, including political dissent and ideological variance. During the 1980s CARICOM experts published a series of reports promoting structural adjustment as necessary for future economic security in the region. These reports erased evidence of widespread objection and political protest against International Monetary Fund reforms, including those expressed by Jamaican Prime Minister, Michael Manley (McAfee 1991).

CARICOM's position is, of course, ambivalent. However, it is because integration is so malleable, and for small, predominantly island states, almost vital, that CARICOM mediation of the nexus between the global economy and communities within the region becomes so significant. It is here that 'the region' absorbs a varied field of political projects at the same time as it becomes object of a series of governmental technologies designed to promote market favourable conduct.

\section{Regional subjects}

Reflecting Foucault's core interests in bio-power and the rise of disciplines of the self, Rose (1989) suggests that while neoliberalism has particular implications for economic organizations, such as companies and institutions, it also has consequences for individuals who are expected to become 'entrepreneurs of themselves' (226). The 'entrepreneurial individual' Rose and Miller (1992: 200) describe as “endowed with freedom and autonomy" is conversely, enabled through a wide range of governmental techniques. Consider, for example, the European Union educational policies described by Katharyne Mitchell (2006) or the Shanghai management workshops Ong (2006) suggests were designed to 'rewire' Chinese attitudes and encourage white collar workers to "embrace values of self-motivation and self-improvement aligned with a corporate vision" (222). Such techniques do not compel individuals to adopt neoliberal identities but they do work to encourage and make attractive behaviours in keeping with particular forms of economic order.

Over the last two decades, CARICOM initiatives have increased the visibility of a regional subject, clearly linked to market friendly attributes such as mobility, entrepreneurialism and skills transferability. The 1989 Conference of the Heads of Government in Grand Anse, Grenada, at which Heads agreed to the CSME in principle, marked the entry of 'a regional people' into what was, until that point, a state-centred discourse on integration. The Grand Anse Declaration claimed, "people, rather than institutions are the creators and producers of development" and initiated a series of public engagements with the wider community for deliberation on the future Development of the region. One such initiative was the Caribbean Regional Economic Conference, held in Trinidad and Tobago February 27 to March 1, 1991, to which nongovernment organizations, private sector organizations and labour unions, were invited to engage directly with Heads of Government (CPDC 1992). The Conference was 
characterised by bitter opposition between participants, much of which centred on the role envisioned for 'people' as the 'creators producing Development'.

Representing the Caribbean Policy Development Center, Antrobus (1991) agreed with the sentiment of the Grande Anse declaration to involve "the mass of populations, in releasing...creativity toward finding solutions" (6). However, she argued this would require a move away from market-led development as rather than freeing Caribbean peoples, market orientation would merely intensify historical dependencies. NGOs requested discussions on gender, structural adjustment, poverty, and the informal sector, and insisted that any government claim to be invested in the quality of life for people in the region needed to be set against their apparently willing ascension to the demands of the global market economy. CARICOM, however, managed the Conference so that the agenda centred on "increased productivity and growth" and strategies to maximize "human resource potential". Despite the debate, the Final Consensus presented at the conclusion of the Conference claimed, "Development is for people, therefore, the Development of Human Resources will be assigned the highest priority in Caribbean development strategies” (CARICOM 1991: 4). In this single document, CARICOM foregrounded the economic contributions of Caribbean peoples, erased disagreement, and claimed the authority of public consensus by repeatedly asserting 'the social partners agree'.

These events draw attention to conflict between competing versions of the region and the particular role performed by CARICOM in managing disagreement and making visible a limited set of subjectivities frequently contained within discourses of 'human resources' and 'social partnership' (Sending \& Neumann 2006). In 1997, CARICOM further elaborated the qualities of 'the ideal Caribbean person' in its document 'Creative and Productive Citizens for the Twenty-First Century’. It declared, a Caribbean person is someone who is tolerant, respectful of diversity, and confident, yet in possession of a strong work ethic, innovativeness in the application of science and technology, and an aptitude for entrepreneurialism (CARICOM 1997a). The CSME signals this ideal Caribbean subject as its beneficiary, in as much as it expected to embrace the right to access a single economic space, sell goods, establish businesses and invest capital.

CARICOM has introduced a number of new techniques to facilitate the desirable activities of the entrepreneurial subject, including rights to free movement within the Community (Article 45). At the time of going to press, Member States are in the process of passing legislation to introduce a CARICOM passport, which details holders as CARICOM nationals first and country nationals second. For many this may ease travel throughout the region but longer term movements related to work have been limited to those who possess advanced skills. Article 46 of the Revised Treaty qualifies and instructs that implementation should begin by extending rights to free movement only to certain classes of persons; namely, University Graduates, Media Persons, Artists, Musicians and Sportspersons. Mobility under the CSME, therefore, is not concerned with the movement of an unqualified category of worker but with the specific movement of skills.

Qualification as a bearer of skills requires a Certificate of Recognition of CARICOM Skills Qualification, only available on submission of a valid passport, certified copies of 
relevant qualifications and a police certificate of character. Additional initiatives to support the mobility and flexibility of skills include social security transferability, harmonization of social services and the development of "common standards and measures for accreditation and equivalency” (CARICOM 2006b). There is clearly a social welfare element to these provisions but the emphasis is on supporting the mobility of the entrepreneurial subject and the economic efficiency of their skills attributes. With the introduction of the CSME the skills bearer has become a regional resource, made visible and subject to regulation at this expanded level. What these initiatives suggests is a reworking of the imagined subjects of Developmentalist discourses, in which the hopes and aspirations of recently independent peoples were linked to national prosperity and independence, into a more individualized and opportunistic discourse of Caribbean subjectivity. This representation erases particular class, gender and racial identities and the unevenness of opportunities available within the region for beneficial participation in a smooth economic space.

\section{CARICOM experts}

The sorts of initiatives I have discussed above are political processes in the sense that they work toward the ordering of behaviours, transactions and relations, and in a direction conducive to the achievement of market rule. They work to make the region intelligible as a smooth transaction space populated by mobile, highly skilled and selfmotivated economic subjects. The persistent reassertion of the ultimate authority of Member States and the subsequent positioning of CARICOM as outside government, places the regional dimensions of these practices beyond politics. CARICOM emerges from its own self-representation as just a technical and administrative institution, populated by invisible subjects, implied only in the performance of their service to Member States. However, experts, scientific knowledge and administration are central practices enabling the relocation of controversial issues into a domain of agreeable truths and objective technical solutions (Ferguson 1994, Rose \& Miller 1992). An analytics of governmentality draws attention to the work CARICOM Secretariat staff do at the interface Ong (2006) describes "between government and knowledge through which governing activities are recast as non-political and nonideological problems that need technical solutions” (3).

Despite the representation of CARICOM as 'just an intergovernmental organization', Secretariat staff actually perform quite a lot of work: conducting research, organizing information, collating statistics and representing the region in tables and charts, analyzing trends, predicting impacts and assessing policy alternatives. In carrying out these tasks, they engage with particular sets of knowledges and favoured rationalities. CARICOM is responsible for co-ordinating "the activities of donor agencies, international, regional and national institutions for the achievement of the objectives of the Community” (CARICOM n.d.). CARICOM staff work directly at this interface, interpreting, translating and cross-referencing the demands of the IMF, World Bank, European Union, World Trade Organization, USAID, among others. The draft CARICOM Financial Services Agreement, for instance, with which I began my discussion of CARICOM's governmental effects was drafted in accordance with a range of international benchmarks and standards, including the International Organization of Securities Commissions, International Association of Insurance Supervisors and the Basel Guidelines on International Banking. 
Recognizing this work is not to suggest Secretariat staff directly support the neoliberalization of the region. Many at the Secretariat are politically supportive of other forms of regionalism and others view their employment there as a way to work strategically from the 'inside'. What it does suggest is the need to consider Secretariat staff as agents, with rich and relational biographies, active in spatially ordering and extending diverse and dispersed modes of governmentality. Staff engage in domesticating externally imposed policies; cleaning regulation of its ideological origins and placing it within a rational management framework officially designed to service the region. As CARICOM staff write their reports through local discursive frames, proposed policies become more palatable and, bolstered by regional statistics and local expert knowledge, legitimated as rational policy instruments outside politics. Such representations are not merely acts legitimating policies formulated elsewhere but one of the many productive points where neoliberalism meets other rationalities, where tensions between the multiple claims on the region are partially resolved and new forms of subjectivities articulated. The neoliberalization of the region begins to emerge from this work as a rational project and, powerfully delimitated into clearly defined and measurable steps, it becomes more readily self-evident and necessary.

\section{Conclusion}

My aim in approaching CARICOM as a site of shifting and dispersed relations, simultaneously productive of definable, and therefore governable, spaces, subjects and objects, has been to highlight the opportunities for expanding understandings of how people and places are brought into relation with neoliberal economic relations. While I have placed an emphasis on the neo-liberalization of Caribbean social realities, I have also stressed the possibilities an analytics of governmentality may hold for recognizing the ambivalence and instability of neoliberal regionalism. For example, 'social partnership' discourses and evidence of dissent written out, flag the possibility for a range of alternative regional subjectivities. Feminist activists have found in CARICOM's 'Women's Desk', an opportunity to advance some of their political concerns, including the regional dissemination of Draft Legislation on gender equality. Even measures such as those that render regional space calculable can produce alternative outcomes. As Barry (2002) suggests, while techniques of calculation have obvious anti-political effects, they simultaneously "provide the basis for an opening up of new objects and sites of disagreement” (274).

Rather than close down politics, therefore, the goal has been to politicize regional arrangements, such as CARICOM. Contrary to the perceived ineffectiveness of regionalism and the rhetoric of national dependency that dominate debates about CARICOM, analysis of the routine practices which order regional space suggests regional agreements need to be much more actively engaged and politicised.

CARICOM is now engaged in a public relations exercise to promote the CSME as 'the region's globalization fight back'. The discourse is optimistic, dynamic and future oriented. The CSME office in Trinidad and Tobago recently launched the 'CSME Caravan', a mobile media exercise with full sound system, food, balloons and information packs. Region-wide TV and radio slots, 'sensitization seminars' as well as press features complement the drive to align public sentiment with the objectives of the CSME. What remains unclear, however, is how the CSME will benefit the vast 
majority of the population in the region. Mobility is limited for those without money to invest or certificates of in-demand skills. The CSME addresses an already-mobile elite while a marginal majority, including banana farmers, unemployed factory workers, and informal traders - arguably the very people impacted by the pressures the CSME is claimed to mitigate - fail to find presence. Understanding how CARICOM works as an exercise in governmentality, connected to new forms of making neoliberal rationalities practicable, can help make visible the politics of such exclusions, the unevenness that is obscured by discourses of smoothness, and the apparently innocuous technical rationalities that work to produce cohesion and manage difference among the competing publics enframed by 'the region'.

\section{Acknowledgements}

This paper is based on research funded by a National Science Foundation Doctoral Dissertation Improvement Grant. It has been much improved by the thoughtful recommendations of two anonymous reviewers. 


\section{References}

Barry A (2002) The anti-political economy. Economy and Society 31(2), 268-284

Barry A, Osborne T and Rose N (1996) Introduction. In Barry A, Osborne T and Rose N (eds) Foucault and Political Reason: Liberalism, Neo-liberalism and rationalities of government University of Chicago Press, Chicago

Beckford G (1972) Persistent Poverty: Underdevelopment in Plantation Economies of the Third World Oxford University Press, London and New York

Bergeron S (2001) Political Economy discourses of globalization and feminist politics. Signs 26(4), 983-1006

Bernal RL (1994) CARICOM: externally vulnerable regional economic integration. In Bouzas R and Ros J (eds) Economic Integration in the Western Hemisphere University of Notre Dame Press, Notre Dame and London

Blake B and Hall K (1980) Integration Experience: Institutional and Policy Aspects CARICOM Documentation Center, Georgetown, Guyana

Bryan AT (1998) Towards 2000: The Caribbean confronts changing trends in international trade. Caribbean Affairs 8(1), 17-40

CAFRA (1998) Research on the impact of new trade agreements on rural women Caribbean Association of Feminist Research and Action, St Augustine, Trinidad and Tobago

CARICOM (1973) Treaty establishing the Caribbean Community, Chaguaramas July 4th, 1973 Caribbean Community Secretariat, Georgetown, Guyana

CARICOM. Creative and Productive Citizens for the Twenty-First Century [Article on the Internet] 1997a [Accessed: January 5th, 2004]. Available from:

http://www.caricom.org/jsp/communications/meetings_statements/citizens_21_century.j sp?menu=communications\#VISION

CARICOM (1997b) Montego Bay Declaration Caribbean Community Secretariat, Georgetown, Guyana

CARICOM (2001) Revised Treaty of Chaguaramas Establishing the Caribbean Community Including the Single Market and Economy Caribbean Community Secretariat, Georgetown

CARICOM. CaricomLaw [Article on the Internet] 2005 [Accessed: November 8th, 2006]. Available from: http://www.caricomlaw.org/about.php 
CARICOM. The CARICOM Single Market and Economy [Article on the Internet] 2006b [Accessed: November 12th, 2006]. Available from:

http://www.caricom.org/jsp/single_market/single_market_index.jsp?menu=csme

CARICOM. CSME: The region's globalisation fight back [Article on the Internet] 2006c [Accessed: 20th November, 2006]. Available from:

http://www.caricom.org/jsp/pressreleases/pres217_06.jsp

CARICOM. The CARICOM Single Market and Economy (CSME) [Article on the Internet] 2007 [Accessed: May 5th, 2007]. Available from:

http://www.caricom.org/jsp/single_market/single_market_index.jsp?menu=csme

CARICOM. Structure of the Community [Article on the Internet] n.d. [Accessed:

November 14, 2003]. Available from: http://www.caricom.org/archives/structure.htm

Commonwealth Advisory Group (1997) A Future for Small States Overcoming

Vulnerability Commonwealth Secretariat, London

Conway D (1998) Microstates in a macroworld. In Klak T (ed) Globalization and NeoLiberalism: The Caribbean Context Rowman \& Littlefield Publishers, Inc, Oxford

CPDC (1992) Challenges in Caribbean Development: Interventions of NGO's at the CARICOM Regional Economic Conference CPDC, Barbados

Dean M (1999) Governmentality: Power and Rule in Modern Society Sage, London

Dietz J, L. and Pantojas-Garcia E (1994) Neo-liberal policies and Caribbean development: from the CBI to the North American Free Trade Agreement. 21st Century Policy Review 2(1-2), 17-40

Donegan B (2006) Governmental Regionalism: Power/ Knowledge and Neoliberal Regional Integration in Asia and Latin America. Millennium - Journal of International Studies 35(1), 23-51

Ferguson J (1994) The Anti-Politics Machine: "Development", Depoliticization, and Bureaucratic Power in Lesotho University of Minnesota Press, Minneapolis

Ferguson J and Gupta A (2002) Spatializing states: toward an ethnography of neoliberal governmentality. American Ethnologist 29(4), 981-1002

Foucault M (1980) Two Lectures. In Gordon C (ed) Power/Knowledge: Selected Interviews and Other Writings 1972-1978 Pantheon, New York

Foucault M (1991) Governmentality. In Burchall G, Gordon C and Miller P (eds) The Foucault Effect University of Chicago Press, Chicago 
Foucault M (2007) Security, Territory, Population: Lectures at the Collège De France 1977-78 Palgrave MacMillan, Basingstoke

Gamble A and Payne A (eds) (1996) Regionalism and World Order Macmillan, London

Gupta A (1995) Blurred boundaries: the discourse of corruption, the culture of politics, and the imagined state. American Ethnologist 22(2), 375-402

Hall KO (2000) Caricom: Unity in Adversity UWI-CARICOM, Georgetown, Guyana

Hettne B (1999) Globalization and the new regionalism: the second great transformation. In Hettne B, Inotai A and Sunkel O (eds) Globalism and the New Regionalism St. Martin's Press, New York

Hettne B (2005) Beyond the 'new' regionalism. New Political Economy 10(4), 543-571

James CLR (1981) The birth of a nation. In Craig S (ed) Contemporary Caribbean: A Sociological Reader The College Press, Maracas, Trinidad and Tobago

Jayasuriya K (2003) Embedded mercantilism and open regionalism: the crisis of a regional political project. Third World Quarterly 24(2), 339-355

Larner W (2003) Neoliberalism? Environment and Planning D: Society and Space 21, 509-512

Larner W (2005) Neoliberalism in (regional) theory and practice: the Stronger Communities Action Fund in New Zealand. Geographical Research 43(1), 9-18

Larner W and Le Heron R (2002) The spaces and subjects of a globalising economy: a situated exploration of method. Environment and Planning D: Society and Space 20, 753-774

Larner W and Le Heron R (2004) Global benchmarking: participating 'at a distance' in the globalizing economy. In Larner W and Walters W (eds) Global Governmentality: Governing International Spaces Routledge, London and New York

Larner W and Walters W (2002) The political rationality of "new regionalism": Toward a genealogy of the region. Theory and Society 31(3), 391-432

Lemke T (2001) 'The birth of bio-politics': Michel Foucault's lecture at the Collège de France on neo-liberal governmentality. Economy and Society 30(2), 190-207

Marchand MH, Bøås M and Shaw TM (1999) The political economy of new regionalisms. Third World Quarterly 20(5), 897-910 
McAfee K (1991) Storm Signals: Structural Adjustment and Development Alternatives in the Caribbean South End Press, Boston

Mitchell K (2006) Neoliberal governmentality in the European Union: education, training, and technologies of citizenship. Environment and Planning D: Society and Space 24, 389-407

Mitchell T (2006) Society, economy and the state effect. In Sharma A and Gupta A (eds) The Anthropology of the State: A Reader Blackwell Publishing, Malden, MA and Oxford

Mittleman JH (1996) Rethinking the 'new regionalism' in a context of globalization. Global Governance 2, 189-213

Montecinos V (1996) Ceremonial regionalism, institutions and integration in the Americas. Studies in Comparative International Development 31(2), 110-123

Nettleford R (2003) Caribbean Cultural Identity: The Case of Jamaica (Revised) Ian Randle, Kingston

Newstead C (2005) Scaling Caribbean (in)dependence. Geoforum 36(1), 45-58

Ong A and Collier SJ (eds) (2005) Global Assemblages: Technology, Politics, and Ethics as Anthropological Problems Blackwell Publishing, Oxford

Pantojas-Garcia E and Klak T (2004) Globalization and economic vulnerability: the Caribbean and the post-9/11 shift. In Griffith I (ed) Caribbean Security in the Age of Terror: Challenge and Change Ian Randle Publishers, Kingston, Jamaica

Peck J and Tickell A (2002) Neoliberalizing space. Antipode 34(3), 380-404

Phillips N (2003) The rise and fall of open regionalism? Comparative reflections on regional governance in the Southern Cone of Latin America. Third World Quarterly 24(2), 217-234

Ramsaran R (2002) The Caribbean and the global challenge in the 21st century. In Ramsaran R (ed) Caribbean Survival and the Global Challenge Ian Randle Publishers, Kingston, Jamaica

Rose-Redwood RS (2006) Governmentality, geography, and the geo-coded world. Progress in Human Geography 30(4), 469-486

Rose N (1989) Governing the Soul: The Shaping of the Private Self Routledge, New York and London 
Rose N (1996) Governing "advanced" liberal democracies. In Barry A, Osborne T and Rose N (eds) Foucault and Political Reason: Liberalism, Neo-liberalism and Rationalities of Government University of Chicago Press, Chicago and London

Rose N and Miller P (1992) Political power beyond the state: problematics of government. The British Journal of Sociology 43(2), 173-205

Schiff M and Winters A (2003) Regional Integration and Development World Bank, Washington, DC

Sending OJ and Neumann IB (2006) Governance to governmentality: analyzing NGO's, states, power. International Studies Quarterly 50, 665-672

Shadlen K (2008) Globalisation, Power and Integration: The Political Economy of Regional and Bilateral Trade Agreements in the Americas. Journal of Development Studies 44(1), 1 - 20

Sharma A and Gupta A (eds) (2006) The Anthropology of the State: A Reader Blackwell Publishing, Malden, MA and Oxford

Smith N (1995) Remaking scale: competition and cooperation in prenational and postnational Europe. In Eskelinen $\mathrm{H}$ and Snickers F (eds) Competitive European Peripheries Springer, Heidelberg

Söderbaum F (2004) Modes of Regional Governance in Africa: Neoliberalism, Sovereignty Boosting, and Shadow Networks. Global Governance 10, 419-436

Staeheli LA and Cope MS (1994) Empowering women's citizenship. Political Geography 13(5), 443-460

Swyngedouw E (2005) Governance, innovation and the citizen: the Janus face of governance-beyond-the-state. Urban Studies 42(11), 1991-2006

Thomas CY and Brewster H (1967) Dynamics of West Indian Economic Integration Kingston

Walters W (2004) The political rationality of European integration. In Larner W and Walters W (eds) Global Governmentality: Governing International Spaces Routledge, London and New York

\footnotetext{
${ }^{\text {i }}$ Barbados, Belize, Guyana, Jamaica, Suriname and Trinidad and Tobago formalised their entry while Antigua and Barbuda, Dominica, Grenada, St Kitts and Nevis, Saint Lucia and St Vincent and the Grenadines agreed to sign once mechanisms for less developed states within the region were agreed. The Bahamas is not yet a part of the Single
} 
Market arrangement, while Montserrat, a British Dependency, awaits decision from the United Kingdom. Haiti is ineligible to participate in the CSME because it has yet to sign the Revised Treaty establishing CARICOM.

ii Söderbaum (2004) suggests in the case of Africa, neoliberal regionalism co-exists with sovereignty boosting regionalism and regional shadow governance. 